\title{
Water-Pipe Tobacco Smoking: An Emerging Health Risk Behavior in Adolescents in the United States
}

\author{
Walid Abuhammour ${ }^{1,2}$, Nida Yousef $^{3}$, Joyvina Evans $^{4}$, Rudayna Zureikat ${ }^{4}$, Mutaz Abuhammour ${ }^{4}$ \\ and Rashed A. Hasan ${ }^{*}, 5$ \\ ${ }^{I}$ Department of Pediatric Infectious Disease, Hurley Medical Center, Michigan State University, Flint, MI, USA \\ ${ }_{2}^{2}$ Pediatric Infectious Diseases, Hurley Medical Center, Flint, MI, USA \\ ${ }^{3}$ Hurley Medical Center - Michigan State University, College of Human Medicine, Flint, MI, USA \\ ${ }^{4}$ Hurley Medical Center, Flint, MI, USA \\ ${ }^{5}$ University of Toledo Medical School, St. Vincent Mercy Children's Hospital, Toledo, OH, USA
}

\begin{abstract}
Objective: To assess the attitude and practices of adolescents regarding water-pipe smoking (WPS) in a predefined 'perceived' high risk group of youth 12-18 years of age in the Detroit metropolitan area.

Methods: This was a cross-sectional survey (conducted March $1^{\text {st }}$ through June $30^{\text {th }}, 2008$ ) in which participants completed a self-reported questionnaire, which included demographics, WPS, other types of smoking, and their perception about the hazards of WPS.

Results: A total of 272 [85\% response rate (272/320] surveys were completed. One hundred and sixty seven (61\%) were WPS "users". Fifty-six (22\%) used WPS at home, $34(13 \%)$ at coffee shops, $74(29 \%)$ at both locations, and $3(1 \%)$ at other locations. Relative to non-users, WPS users were more likely to be cigarette smokers $(\mathrm{OR}=1.7$, unadjusted $\mathrm{OR}=$ $2.5, \mathrm{p}<0.05)$, to have someone else in the household who uses WPS (OR $=2.2)$, to believe that WPS is safe (OR $=1.4$, unadjusted $\mathrm{OR}=2.0)$ and that WPS is less harmful than cigarettes $(\mathrm{OR}=1.2$ unadjusted $\mathrm{OR}=1.6, \mathrm{p}<0.05)$. In addition WPS use was associated with less likelihood of believing that one may acquire an infection $(\mathrm{OR}=0.9)$ and that the toxicity of the inhalants was equivalent to cigarette smoking $(\mathrm{OR}=0.8)$.
\end{abstract}

Conclusions: WPS represents a growing public health issue for adolescents in the US. Aggressive education of adolescents is essential in combating the misperception associated this form of smoking.

Keywords: Water-pipe smoking, argile, shisha, hoka.

\section{INTRODUCTION}

Water-pipe tobacco smoking (WPS) is known by a number of different names, including argileh, hookah, goza, and shisha $[1,2]$. A water-pipe consists of a hose with a mouthpiece, water bowl, body, and a "head" that is filled with sweetened and flavored tobacco and then heated with charcoal [2]. During inhalation from the mouth piece, the smoke from the charcoal and tobacco passes through the body, bowl, and hose into the smoker's lungs.

The use of WPS is spreading worldwide [1]. Limited data show that use of WPS may be on the rise in the USA [3]. This phenomenon has been attributed to the perception that WPS is less dangerous than cigarette smoking, combined with easy availability and relatively low cost [2-4]. WPS is usually a social activity, engaged in by peer groups and families, and is often practiced in special cafes [2]. The expanding influence of globalization places WPS as a

*Address correspondence to this author at the University of Toledo Medical School, St. Vincent Mercy Children's Hospital, 2213 Cherry St., Toledo, OH 43608, USA; Tel: 419-251-4855; Fax: 419-251-3264;

E-mail: rashedh48@hotmail.com potentially important public health issue for adolescents $[1$, 2]. There is a paucity of epidemiological research regarding the use of WPS in general and in adolescents in particular in the US [3].

The purpose of this descriptive, self-reported survey was to assess the attitude and practices of adolescents regarding WPS in a predefined 'perceived' high risk group of youth 12-18 years of age in the Detroit metropolitan area.

\section{METHODS}

Children 12-18 years of age who resided in the Detroit metropolitan area were eligible for enrollment in the study. Individuals were invited by research assistants to participate in the study at coffee shops, social organizations, and two university campuses on weekend days (Friday, Saturday, and Sunday). Weekend days were chosen, because users of WPS tend to use it on weekends. The survey was conducted March $1^{\text {st }}$ through June $30^{\text {th }}, 2008$.

Because participants remain anonymous and since there was no risk to subjects as a result of enrollment in this study, only a verbal consent was obtained from the legal guardian prior to participation in this study. Participants completed a self-reported questionnaire. 


\section{Questionnaire}

The questionnaire consisted of 20 questions, some open ended and some multiple choice, aimed at collecting data on the individuals' demographic characteristics and their smoking behavior with regard to WPS. The following data were collected pertaining to each individual: age, sex, place of family residence, WPS pattern of the individual and his or her family members, other types of smoking, and the individual's perception regarding the hazards of WPS.

Each individual's smoking status was classified according the World Health Organization criteria [5]:

- Daily smokers, defined as individuals who at the time of the survey used WPS daily; these individuals were considered current "users" for the purpose of this study

- Occasional smokers, individuals who smoked waterpipes, but less than once a day

- $\quad$ Former smokers, individuals who smoked daily for at least six months, but did not smoke at the time of the survey

- $\quad$ Never smokers, individuals who had never used WPS and they were considered "non-users" for the purpose of this study

\section{Statistical Analyses}

Logistic regression was used to compare the two groups (current users and non-users). Covariates included age, gender, other forms of tobacco smoking, and perceptions related to harmful effects of WPS. Bivariate logistic analyses were conducted as a first step, after which age, gender, and ethnicity were forced into a multivariate logistic model. All variables that were statistically significant $(p<0.05)$ in bivariate analyses were then entered as a block and nonsignificant variables were removed using backward elimination to arrive at a final model. Odds ratios (ORs), adjusted and unadjusted (crude), and 95\% confidence intervals $(95 \% \mathrm{CI})$ were reported for variables in the final model. All statistical analyses were conducted using SAS version 9.1 (SAS Institute, Cary, NC, USA).

\section{RESULTS}

A total of 272 [85\% response rate (272/320)] surveys were completed. Participants had a mean age of $16.2 \pm 1.4$ years. There was no statistically significant difference between the non-responders and responders with regard to age and ethnic background. Table 1 describes the main clinical characteristics of participants. Overall $61 \%$ used WPS daily and were current "users", $31 \%$ were "non-users", $4 \%$ were occasional users, and $3.5 \%$ were former users. Seventy-three percent of "users" were boys and $27 \%$ were girls. Seventy one percent of Arab-American youth were users, whereas only $40 \%$ of Caucasians were current users of WPS.

Water-pipe tobacco smoking users (Table 2) were statistically older $(16.1 \pm 1.3$ vs $16.7 \pm 1.2$ years, $\mathrm{p}<0.05)$. Fifty-six (20\%) used WPS at home, $34(12.5 \%)$ at coffee shops, $74(27.2 \%)$ at both locations, and $3(1 \%)$ at other locations.
Table 1. Demographics and Tobacoo Use Characteristics of the Study Group $(n=272)$

\begin{tabular}{|c|c|}
\hline Characteristic & $\%$ of Sample \\
\hline \multicolumn{2}{|l|}{ Gender } \\
\hline Male & 73 \\
\hline Female & 27 \\
\hline \multicolumn{2}{|l|}{ Race/ethnicity } \\
\hline Arab-American & 77 \\
\hline Caucasian & 12 \\
\hline African-American & 5.4 \\
\hline Hispanic & 2.7 \\
\hline Other & 1.5 \\
\hline Daily users of WPS* & 61 \\
\hline Occasional users of WPS & 4.5 \\
\hline Former users of WPS & 3.5 \\
\hline Never used WPS & 31 \\
\hline Others smoke water-pipe in the household & 53 \\
\hline Do you smoke cigarettes & 17 \\
\hline Do you smoke cigars & 15 \\
\hline Do you smoke marijuana & 11 \\
\hline
\end{tabular}

In a multivariate model (Table 2), Use of WPS (users) was associated with a greater likelihood of also being a cigarette smoker $(\mathrm{OR}=1.7$, unadjusted $\mathrm{OR}=2.5, \mathrm{p}<0.05)$, a greater likelihood of having someone else in the household who also uses WPS $(\mathrm{OR}=2.2)$, a greater likelihood to believe that WPS is safe $(\mathrm{OR}=1.4)$ and that it is less harmful than cigarettes $(\mathrm{OR}=1.2$, unadjusted $\mathrm{OR}=1.6, \mathrm{p}<$ $0.05)$.

In addition WPS was associated with less likelihood of believing that the toxicity of the inhalants from WPS is equivalent to cigarette smoking $(\mathrm{OR}=0.8)$. There was no statistically significant difference between the WPS users and non-users in terms of using marijuana.

\section{DISCUSSION}

This survey suggests that use of WPS may be a common practice among adolescents who are of Middle Eastern descent and who reside in the Detroit metropolitan area. Sixty-one percent of adolescents who completed the survey were current users of WPS. This compares to a frequency of $68 \%$ in adults from the same geographic area (personal communication). We were incredulous to find that one participant was only 12 years old and 8 others were 13 . These figures deserve further epidemiological investigation, and if found to be true would deserve the attention of public health policy makers and academic institutions in the US. The frequency of use of WPS was significantly higher among adolescents of Middle-Eastern background compared to Caucasians ( $71 \%$ vs $40 \%)$. This may be related to the 
Table 2. Characteristics of Non-Users and Current Users of Water-Pipe Smoking

\begin{tabular}{|c|c|c|c|c|c|}
\hline Variable & Response & $\begin{array}{l}\text { Non-Users } \\
(\mathbf{N}=\mathbf{8 5})\end{array}$ & $\begin{array}{l}\text { Users } \\
(\mathrm{N}=167)\end{array}$ & $\begin{array}{l}\text { Unadjusted OR } \\
(95 \% \mathrm{CI}) \#\end{array}$ & $\begin{array}{l}\text { Adjusted OR } \\
(95 \% \text { CI) \#\# }\end{array}$ \\
\hline Age & Mean \pm SD & $16.1 \pm 1.3$ & $16.7 \pm 1.2$ & $1.40(1.1-1.7)^{*}$ & $1.5(1.1-2.1)^{*}$ \\
\hline Gender & $\begin{array}{l}\text { Female } \\
\text { Male }\end{array}$ & $\begin{array}{l}24(36 \%) \\
61(33 \%)\end{array}$ & $\begin{array}{c}43(64 \%) \\
124(67 \%)\end{array}$ & $1.1(0.6-2.0)$ & $1.3(0.5-3.3)$ \\
\hline Waterpipe smoking is safe & $\begin{array}{c}\text { Strongly Disagree } \\
\text { Disagree } \\
\text { Neutral } \\
\text { Agree } \\
\text { Strongly Agree }\end{array}$ & $\begin{array}{l}35(60 \%) \\
25(32 \%) \\
19(27 \%) \\
0(0.0 \%) \\
3(23 \%)\end{array}$ & $\begin{array}{c}23(39 \%) \\
53(67 \%) \\
49(72 \%) \\
28(100 \%) \\
10(76 \%)\end{array}$ & $2.0(1.5-2.7)^{*}$ & $1.4(0.9-2.3)$ \\
\hline $\begin{array}{l}\text { Waterpipe is less } \\
\text { harmful than cigarette smoking }\end{array}$ & $\begin{array}{l}\text { Strongly disagree } \\
\text { Disagree } \\
\text { Neutral } \\
\text { Agree } \\
\text { Strongly Agree }\end{array}$ & $\begin{array}{c}30(51 \%) \\
24(42 \%) \\
15(28 \%) \\
6(12 \%) \\
7(23 \%)\end{array}$ & $\begin{array}{l}28(48 \%) \\
32(57 \%) \\
38(71 \%) \\
43(87 \%) \\
23(76 \%)\end{array}$ & $1.6(1.2-2.0)^{*}$ & $1.2(0.9-1.7)$ \\
\hline $\begin{array}{l}\text { Waterpipe smoking contains Harmful } \\
\text { ingredients }\end{array}$ & $\begin{array}{l}\text { Strongly disagree } \\
\text { Disagree } \\
\text { Neutral } \\
\text { Agree } \\
\text { Strongly Agree }\end{array}$ & $\begin{array}{c}10(24 \%) \\
8(15 \%) \\
14(23 \%) \\
20(42 \%) \\
24(70 \%)\end{array}$ & $\begin{array}{l}31(75 \%) \\
44(84 \%) \\
47(77 \%) \\
27(57 \%) \\
10(29 \%)\end{array}$ & $0.5(0.4-0.7)^{*}$ & $0.6(0.4-1.0)$ \\
\hline I am or can be hooked on water pipe smoking & $\begin{array}{c}\text { Strongly Disagree } \\
\text { Disagree } \\
\text { Neutral } \\
\text { Agree } \\
\text { Strongly Agree }\end{array}$ & $\begin{array}{l}40(54 \%) \\
16(17 \%) \\
9(25 \%) \\
5(27 \%) \\
3(33 \%)\end{array}$ & $\begin{array}{c}34(45 \%) \\
78(83 \%) \\
27(75 \%) \\
13(72 \%) \\
6(66 \%)\end{array}$ & $1.4(1.1-1.9)^{*}$ & $1.6(1.0-2.5)^{*}$ \\
\hline I can get infection from water pipe smoking & $\begin{array}{c}\text { Strongly Disagree } \\
\text { Disagree } \\
\text { Neutral } \\
\text { Agree } \\
\text { Strongly Agree }\end{array}$ & $\begin{array}{l}10(24 \%) \\
10(18 \%) \\
21(28 \%) \\
18(48 \%) \\
17(63 \%)\end{array}$ & $\begin{array}{l}31(75 \%) \\
44(81 \%) \\
53(71 \%) \\
19(51 \%) \\
10(37 \%)\end{array}$ & $0.6(0.4-0.7)^{*}$ & $0.9(0.6-1.5)$ \\
\hline $\begin{array}{l}\text { Toxins that I inhale from waterpipe smoking are } \\
\text { equivalent to cigarette smoking }\end{array}$ & $\begin{array}{c}\text { Strongly Disagree } \\
\text { Disagree } \\
\text { Neutral } \\
\text { Agree } \\
\text { Strongly Agree }\end{array}$ & $\begin{array}{l}6(14 \%) \\
12(21 \%) \\
18(32 \%) \\
22(45 \%) \\
16(53 \%)\end{array}$ & $\begin{array}{l}35(85 \%) \\
44(78 \%) \\
38(67 \%) \\
26(54 \%) \\
14(46 \%)\end{array}$ & $0.6(0.4-0.7)^{*}$ & $0.8(0.5-1.2)$ \\
\hline $\begin{array}{l}\text { Are there other children at home where you use } \\
\text { waterpipe smoking }\end{array}$ & $\begin{array}{l}\text { No } \\
\text { Yes }\end{array}$ & $\begin{array}{l}31(33 \%) \\
46(31 \%)\end{array}$ & $\begin{array}{l}61(66 \%) \\
98(68 \%)\end{array}$ & $1.0(0.6-1.8)$ & $1.6(0.6-3.8)$ \\
\hline Do You smoke cigarettes & $\begin{array}{l}\text { No } \\
\text { Yes }\end{array}$ & $\begin{array}{l}70(35 \%) \\
7(17 \%)\end{array}$ & $\begin{array}{l}128(64 \%) \\
32(82 \%)\end{array}$ & $2.5(1.0-5.9)^{*}$ & $1.7(0.4-7.4)$ \\
\hline Do You smoke cigars & $\begin{array}{l}\text { No } \\
\text { Yes }\end{array}$ & $\begin{array}{l}70(34 \%) \\
7(19 \%)\end{array}$ & $\begin{array}{l}131(65 \%) \\
29(80 \%)\end{array}$ & $2.2(0.9-5.3)$ & $2.9(0.6-14.0)$ \\
\hline Do you smoke marijuana & $\begin{array}{l}\text { No } \\
\text { Yes }\end{array}$ & $\begin{array}{c}69(32 \%) \\
8(32 \%)\end{array}$ & $\begin{array}{c}143(67 \%) \\
17(68 \%)\end{array}$ & $1.0(0.4-2.5)$ & $0.27(0.04-1.5)$ \\
\hline Does anyone else smoke waterpipe at home & $\begin{array}{l}\text { No } \\
\text { Yes }\end{array}$ & $\begin{array}{l}47(43 \%) \\
28(22 \%)\end{array}$ & $\begin{array}{l}62(56 \%) \\
97(77 \%)\end{array}$ & $2.6(1.5-4.6)^{*}$ & $2.26(0.9-5.6)$ \\
\hline
\end{tabular}

$\mathrm{CI}=$ Confidence Interval, $\mathrm{OR}=$ Odds Ratio.

\#Odds Ratios are calculated from univariable logistic regression for current water-pipe usage. Categorical variables are referenced to the other category. Age and the scaled variables are referenced to 1 year and 1 level increases, respectively.

\#\#Odds Ratios are calculated from multivariable logistic regression for current water-pipe usage, adjusting for the other variables in the table. Categorical variables are referenced to the other category.

Age and the scaled variables are referenced to 1 year and 1 level increases, respectively.

$* \mathrm{p}<0.05$. 
influence of family members and the availability of WPS in the home or in the community. We also observed significant misperceptions related to the harmful effects of WPS. This may be a contributing factor to the use of WPS and warrants the attention of public health authorities. Further education of these communities about the hazards of WPS is warranted.

Most studies on the use of WPS have been conducted among adults in the Middle-Eastern countries. Only limited studies from these countries have been published about university or high school students $[3,4,6-10]$. A survey of Lebanese university students found that $32 \%$ used WPS, with higher rates among men compared to women, and no differences according to socioeconomic status [4]. In another study from Lebanon, WPS rate was $14.6 \%$ among adults and $25 \%$ among pregnant women $[8,9]$. The frequency of use of WPS in our study is much higher compared to previous reports and raises significant concern since $50 \%$ of those who start smoking in their adolescent years will go on to smoke for 15-20 years with negative health consequences [1].

In Syria, a cross-sectional survey of 587 university students found that $62.6 \%$ of the men and $29.8 \%$ of the women had ever used WPS, and $25.5 \%$ of the men and $4.9 \%$ of the women were current users. The mean age of initiation of WPS was 19.2 and 21.7 years, respectively. Smoking usually took place in dormitories, restaurants and cafes and was almost always practiced in groups [10].

In Israel, use of WPS has become a growing phenomenon among Jewish youth. A survey of 388 middle and high school students found that $41 \%$ used WPS and $22 \%$ of them smoked water pipe at least every weekend. The rate of WPS was 3 folds greater than cigarette smoking and increased by 4 folds as the student advanced from the seventh grade to the ninth grade. Twenty-five percent of users of WPS reported smoking with their parents $[11,12]$. The cross-sectional nature of our study limits our ability to draw any conclusions with regard to the changes in the pattern of WPS over time in this population.

In the US, questions regarding use of WPS are not included in national surveys such as the health risk behaviors surveillance systems of the Centers for Disease Control and Prevention (CDC) and there are no national data on the use of WPS [12].

Studies about the use of WPS by adolescents in the US are very limited. Eissenberg et al. reported that use of WPS was common among college students in a survey from one university [3]. In this study $20 \%$ of college students reported using WPS in the past 30 days [3]. This number is significantly lower than the number of users in the current study and all participants in the study of Eissenberg et al. were 18 years and older. Eissenberg et al. [3] also noted that those who have used WPS in the past 30 days were more likely to have the perception that WPS was less dangerous and less addictive than cigarette smoking. These results are consistent with the results of the current study. These findings highlight that WPS among youth is becoming a significant public health concern in the US.

In one report where 28 Arab-American adolescents from the state of Michigan participated in a focus group on smoking, $100 \%$ of them reported that they have used WPS in the past [13]. This suggests that use of WPS smoking is a common practice among the youth in this population. Our study confirms these findings. There was a very high frequency of use of WPS among Arab American adolescents. Cultural background and the availability of WPS in the household or in the neighborhood have undoubtedly contributed to these practices in these adolescents.

What is more alarming is the use of WPS among adolescents who are not of Middle-Eastern background. Thirty-one (12\% of current users of WPS) Caucasians, 10 (5.4\%) African Americans, and 6 (2.7\%) Hispanics reported using WPS. Several dozen argileh bars have opened in cities such as Los Angeles, New York, and Detroit. These bars are becoming increasingly popular among high school and college students. With continued immigration and widespread use of the internet these practices are likely to grow in the US since many internet sites praise the practice of WPS and provide sources for buying WPS products.

Pediatricians should be aware of the emerging use of WPS in the western countries including the US and need to be knowledgeable about its many health implications. Pediatricians should be cognizant of the fact that WPS is perceived by the public as less dangerous than cigarette smoking [2]. These misperceptions emanate from the myths that the nicotine content in the WPS is lower than that of cigarettes, that water filters out all dangerous chemicals and that the smoke of WPS is less irritating to the throat, nose and the tracheobronchial tree compared to cigarette smoke $[1,2,6]$. Furthermore, because the WPS tobacco contains fruits such as apples, this adds to the misconception that this is a healthy choice $[1,2,6]$.

Like cigarette smoking the initiation of WPS is often the result of peer pressure and the desire to be accepted by peers $[2,11]$. In this respect WPS may be seen as meeting certain developmental milestone of adolescence such as attaining autonomy and maturity [2]. In one study most ArabAmerican adolescents who participated in a focus group used WPS as their initial method of smoking [13].

Our study has limitations in that the vast majority of participants were youth of Middle-Eastern background and we did not have access to their socioeconomic status. A major limitation of the study is that the selection of participants was at random from the various locations where these youth are known to gather. This may have introduced a selection bias and may have led to overestimation of the frequency of the WPS among youth from this population. The results of this study may not applicable to other metropolitan areas in the US. Another limitation of the study is the nature of the self-reported questionnaire. This may have introduced recall bias and may distort the results of the study.

Public health control measures should be implemented in communities and locations where WPS is commonly practiced. Other measures that have been used in tobacco control such as labeling packages with warning signs about the hazards of smoking, prohibition of sale to minors, and possibly increasing cost of purchasing WPS tobacco products through taxation should also be considered. 
Cigarette smoking is the leading preventable cause of morbidity and mortality in the US and its hazards to health has been extensively studies. Less is known about the epidemiology, and toxicology of use of WPS. Since WPS is at least as dangerous [2] as other forms of smoking and since this is a health risk behavior that is enjoying an impressive revival, there is an urgent need to study this subject and need to create a national data on the use of WPS in the US.

\section{ACKNOWLEDGMENT}

We would like to thank the following individuals for their valuable contribution: George Zureikat, M.D., Ammar Alhmood, M.D., Mahmoud Mahafza, M.D., Ali Lutfi, Mohammed Shenaq and Farah Dubaybo.

\section{REFERENCES}

[1] World Health Organization. TobReg advisory note. waterpipe tobacco smoking: health effects, research needs and recommended actions by regulators. Geneva, Switzerland, World Health Organization 2005.

[2] Knishkowy B, Amitai Y. Water-pipe (Narghile) smoking: an emerging health risk behavior. Pediatrics 2005; 116: e11319.

[3] Eissenberg T, Ward KD, Smith-Simone S, Maziak W. Waterpipe tobacco smoking on a U.S. college campus: Prevalence and Correlates. J Adolesc Health 2008; 42: 526-29.
[4] Tamim H, Terro A, Kassem H, et al. Tobacco use by university students, Lebanon, 2001. Addiction 2003; 98(7): 933-9.

[5] World Health Organization. Guidelines for the conduct of tobaccosmoking surveys among health professionals. Geneva: WHO 1984.

[6] Maziak W, Rastam S, Eissenberg T, et al. Gender and smoking status-based analysis of views regarding waterpipe and cigarette smoking in Aleppo, Syria. Prev Med 2004; 38: 479-84.

[7] Maziak W, Eissenberg T, Rastam S, et al. Beliefs and attitudes related to narghile (waterpipe) smoking among university students in Syria. Ann Epidemiol 2004; 14: 646-54.

[8] Baddoura R, Welbeh-Chidiac C. Prevalence of tobacco use among the adult Lebanese population. East Mediterr Health J 2001; 7: 819-28.

[9] Chaaya M, Awwad J, Campbell OM, Sibai A, Kaddour A Demographic and psychosocial profile of smoking among pregnant women in Lebanon: public health implications. Matern Child Health J 2003; 7: 179-86.

[10] Maziak W, Fouad FM, Asfar T, et al. Prevalence and characteristics of narghile smoking among university students in Syria. Int J Tuberc Lung Dis 2004; 8: 882-89.

[11] Varsano S, Ganz I, Eldor N, Garenkin M. Water-pipe tobacco smoking among school children in Israel: frequencies, habits, and attitudes [in Hebrew]. Harefuah 2003; 142: 736-41.

[12] National Center for Chronic Disease Prevention and Health Promotion. Healthy Youth! Data and Statistics. YRBSS: Youth Risk Behavior Surveillance System. [Accessed April 12, 2008]. Available at: www.cdc.gov/ HealthyYouth?yrbs/index.htm

[13] Kulwicki A, Rice VH. Arab American adolescent's perceptions and experiences with smoking. Public Health Nurs 2003; 20: 177-83. 